\title{
KAJIAN PENCEMARAN EKOSISTEM MANGROVE JENIS Rhizophora mucronata DI PERAIRAN DESA KALIANYAR BANGIL PASURUAN JAWA TIMUR
}

\section{ASSESMENT OF MANGROVE ECOSYSTEM POLLUTION TYPES OF Rhizophora mucronata IN KALIANYAR VILLAGE WATER BANGIL PASURUAN WEST JAVA}

\author{
Ernawati $^{1}$, Eddy Suprayitno ${ }^{2)}$, Hardoko $^{2)}$, Uun Yanuhar ${ }^{2)}$ \\ ${ }^{1}$ Fakultas Pertanian, Universitas Yudharta Pasuruan \\ ${ }^{2)}$ Fakultas Perikanan dan Ilmu Kelautan, Universitas Brawijaya Malang \\ Email : ernawati_thpi@yudharta.ac.id
}

\begin{abstract}
ABSTRAK
Salah satu program utama Pemerintah saat ini adalah mewujudkan Indonesia sebagai poros Maritim dunia antara lain melalui rehabilitasi kerusakan lingkungan dan konservasi biodiversitas. Tujuan penelitian ini adalah untuk mengetahui tingkat pencemaran beberapa logam berat pada tanaman mangrove, perairan dan sedimen di desa Kalianyar Bangil Jawa Timur. Hasil penelitian ini dapat digunakan sebagai data awal oleh Pemerintah Daerah setempat maupun pihak-pihak yang berhubungan dengan penggunaan wilayah laut untuk pelestarian tanaman mangrove secara terpadu dan berkelanjutan. Lokasi Desa Kalianyar dekat dengan muara sungai dimana aliran sungai tersebut berhubungan dengan pembuangan lumpur lapindo. Di wilayah tersebut terdapat habitat mangrove, sehingga dampak pembuangan tersebut diperkirakan dalam jangka waktu tertentu dapat mempengaruhi kehidupan ekosistem mangrove. Hasil penelitian menunjukkan bahwa secara umum kandungan $\mathrm{Pb}, \mathrm{Cu}, \mathrm{Cd}, \mathrm{Hg}$ dan $\mathrm{Fe}$ di perairan sudah melebihi ambang batas yang diijinkan. Kandungan $\mathrm{Pb}$ dan $\mathrm{Cd}$ pada sedimen umumnya masih di bawah ambang batas, sedangkan $\mathrm{Cu}$ dan $\mathrm{Hg}$ sedimen sudah melebihi ambang batas yang ditetapkan. Kandungan logam berat $\mathrm{Cu}, \mathrm{Cd}$ pada sampel buah mangrove melewati ambang batas, sedangkan $\mathrm{Pb}$ dan $\mathrm{Hg}$ sampel buah di bawah ambang batas yang ditetapkan Dirjen POM No. 03725/B/SK/VII/89 tentang toleransi logam berat pada makanan. Hasil pengamatan kualitas air yaitu suhu, pH, kecerahan, DO, BOD, COD, umumnya masih dalam kisaran yang dipersyaratkan, sedangkan amonia melebihi ambang batas untuk kegiatan budidaya perikanan sesuai PP No. 82 Tahun 2001 tentang Pengelolaan Kualitas Air dan Pengendalian Pencemaran Air.
\end{abstract}

Kata kunci : Bangil, lingkungan, logam berat, mangrove, pencemaran

\section{ABSTRACT}

One of the main programs of the Government recently is to actualize Indonesia as a world Maritime country through the rehabilitation of environmental damage and biodiversity conservation. The purpose of this study is to determine the level of pollution of some heavy metals in mangrove, water and sediment in the village of Kalianyar 
Bangil East Java. The results of this study can be used as a reference for Local Government and parties related to the use of marine areas for the conservation of mangrove plants in an integrated and sustainable manner. The location of the village of Kalianyar is close to the mouth of the river where the river is associated with the disposal of Lapindo mud. In the area there is a mangrove habitat, so the impact of disposal is estimated within a certain time can affect the life of mangrove ecosystems. The results showed that in general the content of $\mathrm{Pb}, \mathrm{Cu}, \mathrm{Cd}, \mathrm{Hg}$ and $\mathrm{Fe}$ in waters have exceeded the allowable threshold. The content of $\mathrm{Pb}$ and $\mathrm{Cd}$ in sediments is generally still below the threshold, while $\mathrm{Cu}$ and $\mathrm{Hg}$ have exceeded the set threshold. The heavy metal content of $\mathrm{Cu}, \mathrm{Cd}$ in mangrove fruit samples cross the threshold, while $\mathrm{Pb}$ and $\mathrm{Hg}$ are below the threshold established by Dirjen POM no. 03725 / B / SK / VII / 89 on the tolerance of heavy metals in food. Water quality observations of temperature, $\mathrm{pH}$, brightness, DO, BOD, COD, are generally still within the required range, while ammonia exceeds the threshold for aquaculture activities in accordance with PP no. 82 of 2001 on the Management of Water Quality and Control of Water Pollution.

Keywords : Bangil, environment, heavy metal, mangrove, pollution

\section{PENDAHULUAN}

Indonesia merupakan negara kepulauan dengan $80 \%$ wilayah laut dan $20 \%$ wilayah darat. Kondisi tersebut menyebabkan potensi ancaman terhadap kedaulatan dan wilayah Indonesia berada di laut. Prosentase ancaman ini menjadi semakin tinggi karena posisi geografi Indonesia berada pada lalu lintas perdagangan dunia. Laut Indonesia memiliki arti yang sangat penting bagi Negara Kesatuan Republik Indonesia (NKRI) yaitu, laut sebagai media pemersatu bangsa, laut sebagai media perhubungan, laut sebagai media sumber daya, laut sebagai media pertahanan dan keamanan, serta laut sebagai media diplomasi (Anonim, 2016).

Saat ini bangsa Indonesia mulai menata kembali untuk bisa mengem balikan jiwa kebaharian dan melaksanakan pembangunan kelautan, meskipun belum maksimal. Hal ini didasari pada kesadaran akan ancaman yang mungkin timbul karena faktanya bahwa wilayah laut merupakan wilayah terbuka, maka dengan leluasa kekayaan laut Indonesia berpotensi untuk dimanfaatkan bangsa lain tanpa ada kemampuan untuk melindunginya. Perkiraan ancaman dan gangguan lainnya yang mungkin dihadapi Indonesia ke depan antara lain meliputi kejahatan lintas negara (misalnya 
penyeludupan, penangkapan ikan ilegal), pencemaran dan perusakan ekosistem, imigrasi gelap, pembajakan / perampokan, aksi radikalisme, konflik komunal dan dampak bencana alam.

Ketahanan lingkungan kelautan mendukung kebijakan poros Maritim Indonesia, seiring dengan perkemba ngan dan pertumbuhan industri yang sangat pesat. Penegakan kedaulatan wilayah laut NKRI melalui revitalisasi sektor-sektor ekonomi kelautan, pe nguatan dan pengembangan konektivitas maritim, rehabilitasi kerusakan lingku ngan dan konservasi biodiversitas, serta peningkatan kualitas dan kuantitas SDM kelautan, merupakan program-program utama Pemerintah saat ini guna mewujudkan Indonesia sebagai poros maritim dunia. Ketahanan pangan Maritim perlu ditingkatkan dengan mengeksploitasi komoditi yang berasal dari laut Indonesia yang selama ini kurang didayagunakan (Anonim, 2017).

Aktivitas manusia dalam

memanfaatkan kawasan pesisir seringkali menghasilkan limbah bahan pencemar yang dapat membahayakan kehidupan perairan laut dan secara khusus dapat menganggu perkembangan komunitas wilayah tersebut (Amiard, 2009; Knox., 1986). Wilayah pesisir kebanyakan merupakan tempat ber muara sungai-sungai yang membawa berbagai macam jenis limbah yang bersifat toksik ke perairan pesisir, diantaranya adalah senyawa logam berat, limbah organik dan berbagai limbah buangan industri (Haritash, 2009; Fajri, 2001; Li, 2014).

Desa Kalianyar di Bangil Pasuruan merupakan wilayah yang banyak ditumbuhi mangrove. Lokasinya dekat dengan muara sungai dimana aliran sungai tersebut berhubungan dengan pembuangan lumpur lapindo. Jenis mangrove yang banyak tumbuh disitu dari golongan Rhizophora. Mangrove memiliki fungsi ekologi yang penting, antara lain untuk sekuestrasi karbon, menjaga stabilitas pantai dari erosi, intrusi air laut, dan tekanan badai, membentuk daratan baru, menjaga kealamian habitat, menjadi tempat bersarang, memijah dan membesarkan anak berbagai jenis ikan, udang, kerang, burung, dan fauna lain, serta memiliki fungsi sosial sebagai area konservasi, pendidikan, ekoturisme, dan identitas budaya (Manassrisuksi et al., 2001; Ng 
dan Sivasothi, 2001; Ong, 2002), sehingga perlu dijaga kelestariannya. Hasil buangan lumpur lapindo yang mengalir ke sungai diperkirakan akan dapat mempengaruhi kandungan logam berat dan limbah organik dan mengganggu kehidupan ekosistem mangrove.

Tujuan penelitian ini adalah untuk mengetahui tingkat pencemaran beberapa logam berat pada tanaman mangrove, perairan dan sedimen sebagai akibat limbah industri, domestik maupun pembuangan lumpur lapindo terhadap perairan di sekitarnya. Kajian pencemaran pada ekosistem mangrove perlu dilakukan penelitian berkaitan dengan usaha pembersihan media dan lingkungan tumbuh dimasa yang akan datang dan informasi ini diyakini sangat penting sebagai gambaran awal untuk reboisasi dan pelestarian tanaman mangrove secara terpadu dan berkelanjutan. Hasilnya diharapkan dapat dijadikan acuan baik oleh Pemerintah Daerah setempat maupun pihak-pihak yang berhubungan dengan penggunaan wilayah laut untuk berbagai kepentingan.

\section{METODE PENELITIAN}

Titik sampling

Penelitian ini dilakukan di pe rairan yang ditumbuhi mangrove di wi layah desa Kalianyar Bangil Kabupaten Pasuruan pada tanggal 03-08 Agustus 2017. Penetapan posisi stasiun dilaku kan di tiga titik sampling secara acak yang masih dalam radius ekosistem mangrove yang tumbuh pada aliran sungai sebelum bermuara ke Laut Jawa. Inside peta lokasi penelitian dapat dili hat pada Gambar 1. Sedangkan lokasi pengambilan sampel dapat dilihat pada Gambar 2.

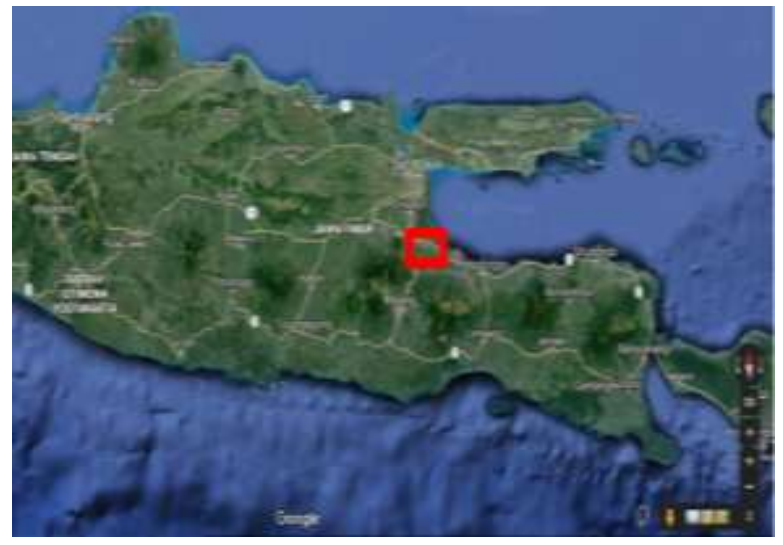

Gambar 1. Inside Peta Lokasi 


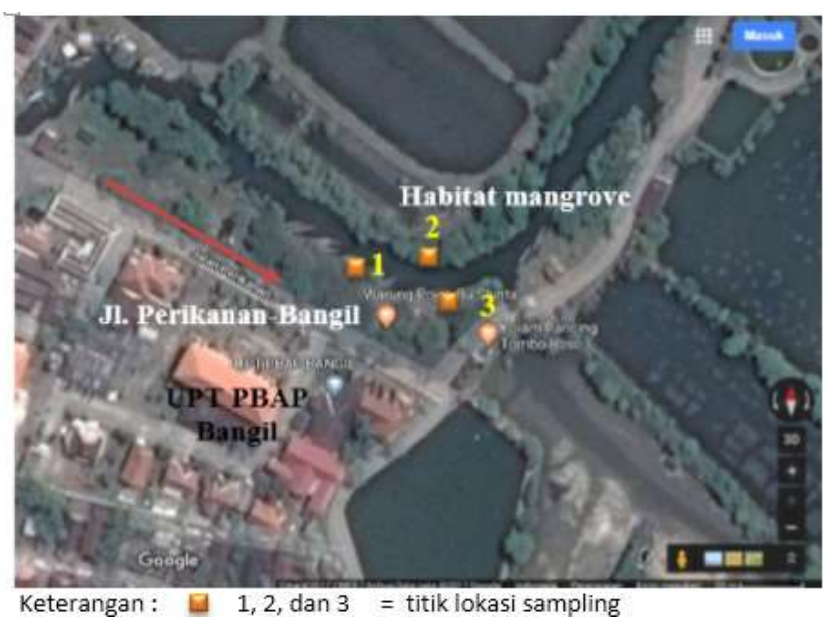

Gambar 2. Lokasi Pengambilan Sampel

\section{Parameter Pengamatan}

Parameter yang diamati adalah logam berat $(\mathrm{Pb}, \mathrm{Cu}, \mathrm{Cd}, \mathrm{Hg}$, dan $\mathrm{Fe})$, kualitas air yang meliputi suhu, kecerahan, derajat keasaman $(\mathrm{pH})$, Dissolve Oxygen (DO), Biochemical Oxygen Demand (BOD), Chemical Oxygen Demand (COD), amonia, dan Total Suspended Solid (TSS)

\section{Prosedur Pengambilan Sampel dan Analisis Sampel Air}

Contoh air diambil sebanyak 1 liter pada lapisan permukaan dengan menggunakan water sampler pada 3 titik lokasi penelitian. Selanjutnya contoh air laut disaring dengan kertas saring selulosa nitrat $(0,45 \mu \mathrm{m})$ yang sebelumnya dicuci dengan $\mathrm{HNO}_{3}(1 \mathrm{~N})$, dan diawetkan dengan $\mathrm{HNO}_{3}(\mathrm{pH}<2)$. Di laboratorium, contoh air diambil sebanyak $250 \mathrm{~mL}$ dimasukkan ke dalam corong pisah teflon, kemudian diekstraksi dengan APDC/MIBK. Fase organik yang diperoleh kemudian diekstraksi kembali dengan $\mathrm{HNO}_{3}$.

\section{Sampel sedimen}

Contoh sedimen diambil pada lapisan permukaan $(0-5 \mathrm{~cm})$ dengan menggunakan grab yang terbuat dari stainless steel. Contoh sedimen dimasukkan ke dalam botol polietilen yang sebelumnya botol tersebut dicuci/ direndam dalam $\mathrm{HNO}_{3}(6 \mathrm{~N})$ dan dibilas dengan air suling.

Di laboratorium, contoh sedimen dimasukkan dalam cawan teflon dan dikeringkan dalam oven pada suhu 105 ${ }^{\circ} \mathrm{C}$ selama 24 jam. Setelah kering dikocok beberapa kali dengan air suling. Contoh sedimen dikeringkan kembali pada suhu $100{ }^{\circ} \mathrm{C}$ selama 24 jam, kemudian digerus hingga halus.

Sebanyak 5 gram contoh sedimen kering dimasukkan dalam cawan teflon, didestruksi dengan menggunakan $\mathrm{HNO}_{3} / \mathrm{HCl}$ pekat dan biarkan pada suhu ruang \pm 4 jam. Destruksi dilanjutkan 
pada suhu $90{ }^{\circ} \mathrm{C}$ selama 8 jam. Analisis

$\mathrm{Pb}, \mathrm{Cd}, \mathrm{Hg}$ ditentukan dengan AAS.

\section{Analisis sampel}

Pengukuran suhu, kecerahan, $\mathrm{pH}$, amonia, DO, BOD, dan COD air dilakukan di lokasi sampling segera setelah sampel air diambil. Pengukuran $\mathrm{pH}$ dilakukan dengan menggunakan $\mathrm{pH}$ meter Hanna HI-98107 sedangkan kecerahan air diukur menggunakan secchi disk. Pengukuran DO menggunakan Elektrometrik, BOD, COD, dan amonia dilakukan dengan menggunakan Colorimetrik Hach DR/ 890 sesuai prosedur operasional alat (Hach, 1999).

Preparasi sampel dan analisis residu logam berat dilakukan di Laboratorium Unit Pelaksana Teknis Pengembangan Budidaya Air Payau (UPT PBAP) Bangil Dinas Kelautah dan Perikanan Provinsi Jawa Timur. Preparasi sampel untuk analisis residu logam berat $(\mathrm{Pb}, \mathrm{Cu}, \mathrm{Cd}, \mathrm{Hg}$, dan $\mathrm{Fe})$ dalam sampel air maupun sedimen dilakukan sesuai dengan metode yang digunakan oleh Hutagalung et al. (1997).
Penentuan kandungan logam berat pada sedimen dilakukan dengan menggunakan Atomic Absorption Spectrophotometer (AAS) Perkin Elmer Analyst 800 (Elmer, 2000), sedangkan kandungan logam berat pada sampel air menggunakan metode Colorimetrik.

\section{HASIL DAN PEMBAHASAN}

\section{Kandungan Logam Berat Pada Air}

Hasil pengamatan kandungan logam berat pada sampel air di perairan muara sungai disajikan pada Tabel 1.

Tabel 1. Kandungan Logam berat sampel air

\begin{tabular}{llcccc}
\hline No & $\begin{array}{l}\text { Para- } \\
\text { meter }\end{array}$ & Unit & Titik 1 & Titik 2 & Titik 3 \\
\hline 1 & $\mathrm{~Pb}$ & $\mathrm{mg} / \mathrm{L}$ & 0,80 & 0,79 & 0,81 \\
2 & $\mathrm{Cu}$ & $\mathrm{mg} / \mathrm{L}$ & 1,18 & 1,19 & 1,22 \\
3 & $\mathrm{Cd}$ & $\mathrm{mg} / \mathrm{L}$ & 0,055 & 0,074 & 0,098 \\
4 & $\mathrm{Hg}$ & $\mathrm{mg} / \mathrm{L}$ & 0,08 & 0,12 & 0,11 \\
5 & $\mathrm{Fe}$ & $\mathrm{mg} / \mathrm{L}$ & 0,02 & 0,03 & 0,03 \\
\hline
\end{tabular}

Berdasarkan Tabel 1 dapat dilihat bahwa hasil pengamatan kandungan logam berat berdasarkan ketetapan Pemerintah melalui PP No. 82 Tahun 2001 bagi usaha perikanan, kandungan $\mathrm{Pb}$ dalam air berkisar $0,79-0,81 \mathrm{mg} / \mathrm{L}$, berada di ambang batas yang diperboleh kan yaitu 0,001-1,157 mg/L. Sementara itu kandungan $\mathrm{Cu}$ yaitu 1,18-1,22 mg/L, 
melewati ambang batas $(\leq 0,025 \mathrm{mg} / \mathrm{L})$. Kandungan Cd berkisar 0,15-0,24 mg/L atau 55-98 ppb sehingga melewati ambang batas $(<10 \mathrm{ppb})$. Kandungan $\mathrm{Hg}$ 0,08-0,12 $\mathrm{mg} / \mathrm{L}$ melewati ambang batas (2 ppb). Kandungan Fe berkisar 0,02$0,04 \mathrm{mg} / \mathrm{L}$ masih berada di bawah ambang batas $(\leq 1,0 \mathrm{mg} / \mathrm{L})$.
Kandungan Logam Berat Pada Sedimen

Kandungan logam berat $\mathrm{Pb}, \mathrm{Cd}$, dan $\mathrm{Hg}$ pada buah mangrove dan sedimen yang diambil dari perairan disajikan pada Tabel 2.

Tabel 2. Kandungan Logam berat dan TDS pada sedimen

\begin{tabular}{lllcccc}
\hline No & Parameter & Unit & $\begin{array}{c}\text { Buah } \\
\text { mangrove }\end{array}$ & Sedimen 1 & Sedimen 2 & Sedimen 3 \\
\hline 1 & $\mathrm{~Pb}$ & $\mathrm{ppm}$ & 0,584 & 0,680 & 0,795 & 0,800 \\
2 & $\mathrm{Cu}$ & $\mathrm{ppm}$ & 1,81 & 2,21 & 2,12 & 1,99 \\
3 & $\mathrm{Cd}$ & $\mathrm{ppm}$ & 0,285 & 0,462 & 0,344 & 0,385 \\
4 & $\mathrm{Hg}$ & $\mathrm{ppm}$ & 0,472 & 0,609 & 0,589 & 0,596 \\
5 & $\mathrm{Fe}$ & $\mathrm{ppm}$ & 1,58 & 2,33 & 2,87 & 2,41 \\
\hline
\end{tabular}

Apabila dibandingkan dengan kandungan logam berat dalam air maka kandungan logam berat pada sedimen umumnya lebih tinggi. Hal ini dapat terjadi melalui proses akumulasi bahanbahan yang tidak larut dalam air yang selanjutnya terendapkan di dasar pe rairan. Tingginya kandungan logam berat pada sedimen erat hubungannya dengan sifat logam berat yang mudah terikat oleh bahan-bahan organik yang ada pada sedimen (Connell \& Miller, 1995 dalam Santoso \& Hernayanti, 2005). $\mathrm{Pb}$ dalam sedimen berkisar 0,680-0,800 ppm, masih di bawah ambang batas. Kadar $\mathrm{Cu}$ pada kisaran 1,99-2,21 melewati ambang batas. Tingginya kandungan $\mathrm{Cu}$ ini diduga karena kebanyakan senyawa $\mathrm{Cu}$ akan menetap dan berikatan dengan partikel sedimen air maupun partikel tanah.

Cd dalam sedimen berkisar antara 0,344-0,462 ppm. Kadar Cd ini relatif tinggi, karena kadar Cd di perairan yang relatif bersih berkisar antara 0,0200,070 ppm. Menurut Thayib dan Razak (1981) kadar normal Cd dalam sedimen yang tidak terkontaminasi berkisar antara 0,1-2,0 ppm. Sedangkan Everaart (1989) menyatakan kadar logam berat 
yang terdapat dalam sedimen yang tidak terkontaminasi paling rendah adalah sebesar 0,01 ppm.

Berdasarkan data di atas dapat dikatakan bahwa sedimen di dasar perairan ini telah terkontaminasi oleh Cd. Seiring dengan berjalannya waktu maka Cd ini juga akan terakumulasi di dalam sedimen dalam jumlah yang lebih banyak lagi, juga di dalam tubuh biota yang hidup dan mencari makan di dalamnya. Berdasarkan kenyataan ini dapat dikategorikan bahwa kualitas sedimen di perairan meskipun belum tercemar, tetapi sudah terkontaminasi oleh logam berat $\mathrm{Cd}$.

Kandungan Hg sedimen 0,5960,609 ppm melewati ambang batas yang dibolehkan (2 ppb). Kandungan alamiah logam berat pada sedimen adalah 20350 ppb untuk $\mathrm{Hg}, 10.000-70.000$ ppb untuk $\mathrm{Pb}, 100-2.000$ ppb untuk $\mathrm{Cd}$, dan 5.000-30.000 ppb untuk $\mathrm{Cu}$ (Rozak, 2007).

Pencemaran yang terjadi baik di laut maupun di daratan dapat mencapai kawasan mangrove, karena habitat ini merupakan ekosistem antara laut dan daratan. Bahan pencemar seperti minyak, logam berat, sampah, dan limbah industri dapat menutupi akar mangrove sehingga mengurangi kemam puan respirasi dan osmoregulasi tumbuhan mangrove, dan pada akhirnya menyebabkan kematian. Hutan mang rove penting terhadap lingkungan karena memiliki peranan atau fungsi yang penting baik fungsi fisik, fungsi kimia, fungsi biologi, fungsi ekonomi dan fungsi wisata. Apabila hutan mangrove rusak atau bahkan hilang, banyak kerugian yang harus ditanggung manusia ataupun makhluk hidup lainnya serta lingkungan, seperti moluska, kepiting, ikan, udang, dan biota lainnya.

\section{Kualitas Air pada perairan ekosistem mangrove \\ Hasil pengamatan kualitas air meliputi $\mathrm{pH}$, suhu, DO, BOD, COD, salinitas, $\mathrm{NH}_{3}$, kecerahan, dan TOM disajikan pada Tabel 3 berikut ini.}


Tabel 3. Hasil Pengamatan Kualitas Air

\begin{tabular}{ccccccc}
\hline No & Parameter & Unit & Stasiun 1 & Stasiun 2 & Stasiun 3 & Rata-rata \\
\hline 1 & $\mathrm{pH}$ & - & 8,4 & 7,9 & 8,2 & 8,17 \\
2 & Suhu & $\mathrm{oC}$ & 27,9 & 27,8 & 27,9 & 27,87 \\
3 & $\mathrm{DO}$ & $\mathrm{mg} / \mathrm{L}$ & 5,31 & 5,28 & 5,30 & 5,30 \\
4 & $\mathrm{BOD}$ & $\mathrm{mg} / \mathrm{L}$ & 20 & 21 & 20 & 20,33 \\
5 & $\mathrm{COD}$ & $\mathrm{mg} / \mathrm{L}$ & 68 & 68 & 65 & 67,00 \\
6 & $\mathrm{TOM}$ & $\mathrm{mg} / \mathrm{L}$ & 116,92 & 115,50 & 117,50 & 116,64 \\
7 & Salinitas & $\mathrm{ppt}$ & 10 & 12 & 9 & 10,33 \\
8 & NH3 & $\mathrm{mg} / \mathrm{L}$ & 0,28 & 0,28 & 0,30 & 0,29 \\
9 & Kecerahan & $\mathrm{cm}$ & 27 & 24,5 & 25 & 25,50 \\
10 & TSS & $\mathrm{mg} / \mathrm{L}$ & 66 & 70 & 72 & 69,33 \\
\hline
\end{tabular}

Hasil pengamatan menunjukkan bahwa pH air relatif stabil, berkisar 7,98,4 . Nilai $\mathrm{pH}$ tersebut masih memenuhi persyaratan untuk kegiatan budidaya perikanan yaitu 7-9 (Effendi, 2003). Suhu dan kecerahan air pada saat pengamatan masing-masing berkisar $27,8-27,9^{\circ} \mathrm{C}$ dan $24,5-27 \mathrm{~cm}$. Kisaran nilai suhu masih dalam batas yang normal untuk kehidupan akuatik. Sedangkan tingkat kecerahan tergolong pekat karena pada nilai di bawah $40 \mathrm{~cm}$. Tingkat kecerahan akan berpengaruh terhadap proses penetrasi cahaya ke dalam air serta proses fotosintesis fitoplankton yang diperlukan untuk memelihara tingkat kesuburan perairan. Menurut Andriyani (2005), kisaran nilai kecerahan yang dipersyaratkan untuk kehidupan akuatik minimal 0,45 m.
Kandungan DO dan BOD masih baik dan sesuai dengan baku mutu air yang dipersyaratkan untuk kegiatan budidaya perikanan (PP No. 82 Tahun 2001). Ambang batas minimal DO sebesar $3 \mathrm{mg} / \mathrm{L}$ sedangkan untuk BOD < 25 mg/L. Kandungan COD berkisar 65$68 \mathrm{mg} / \mathrm{L}$ yang berarti sudah melewati ambang batas yang dipersyaratkan untuk kegiatan budidaya perikanan $(<40$ $\mathrm{mg} / \mathrm{L})$.

Kandungan COD yang tinggi menunjukkan keberadaan limbah anorganik di perairan cukup tinggi. Limbah anorganik yang diduga berasal dari kegiatan industri dan domestik. Kadar amoniak $\left(\mathrm{NH}_{3}\right)$ pada kisaran 0,28-0,30 $\mathrm{mg} / \mathrm{L}$ melewati ambang batas (0,05-0,10 mg/L). 01). Kandungan amonia yang melebihi ambang batas merupakan salah satu indikator 
terjadinya pencemaran biologis pada suatu perairan, karena amonia merupakan hasil dekomposisi senyawa biologis oleh mikroorganisme. Amonia merupakan racun yang berbahaya bagi biota perairan (Effendi, 2003).

\section{Analisis Zat Padat}

Hasil pengamatan Bahan organik terlarut total atau Total Organik Matter (TOM) dan Total suspended solid (TSS) dapat dilihat pada Tabel 3.

TOM hasil penelitian mempunyai kisaran nilai 115-117,5 mg/L. TOM menggambarkan kandungan bahan organik total suatu perairan yang terdiri dari bahan organik terlarut, tersuspensi (particulate) dan koloid. Astari (2003) menyebutkan bahwa perairan dengan kandungan $\quad$ TOM $\quad \leq 10 \quad \mathrm{mg} / \mathrm{L}$ dikategorikan sebagai perairan yang bersih. Sementara pendapat lain menyatakan bahwa standar perairan yang subur bisa berkisar antara 26-70 ppm sedangkan lebih dari itu perairan tersebut dikatakan sebagai perairan yang tidak sehat atau kotor / tercemar. Kadar bahan organik terlarut sampel yang diteliti di atas nilai ambang batas, sehingga digolongkan perairan tercemar.

Hasil pengamatan TSS (total suspended solid) pada sampel air didapatkan kisaran nilai 66-72 mg/L. Zat Padat Tersuspensi (TSS) adalah padatan yang menyebabkan kekeruhan air, tidak terlarut dan tidak dapat langsung mengendap, terdiri dari partikel-partikel yang ukuran maupun beratnya lebih kecil dari sedimen, mi salnya tanah liat, bahan-bahan organik tertentu, sel-sel mikroorganisme, dan sebagainya. TSS berhubungan erat dengan erosi tanah dan erosi dari saluran sungai, transportasi fosfor, logam, dan berbagai bahan kimia industri dan pertanian dengan nilai bervariasi mulai $\leq 5 \mathrm{mg} / \mathrm{L}$ sampai yang paling ekstrem $30.000 \mathrm{mg} / \mathrm{L}$ di beberapa sungai.

\section{KESIMPULAN}

Berdasarkan data yang dikaji maka dapat disimpulkan:

- Kandungan logam berat $\mathrm{Pb}$, dan $\mathrm{Fe}$ dalam sampel air masih di bawah ambang batas, sedangkan kadar $\mathrm{Cu}$, Cd, dan Hg sudah melebihi ambang 
batas yang ditetapkan dengan NAB untuk kepentingan biota laut.

- Kandungan logam berat $\mathrm{Pb}$ dan $\mathrm{Cd}$ dalam sedimen relatif rendah, sedangkan $\mathrm{Cu}$ dan $\mathrm{Hg}$ sudah melebihi ambang batas.

- Kandungan logam berat pada sampel buah mangrove untuk nilai $\mathrm{Cu}, \mathrm{Cd}$ melewati ambang batas, sedangkan $\mathrm{Pb}$ dan $\mathrm{Hg}$ di bawah ambang batas yang ditetapkan Dirjen POM No. 03725/B/SK/VII/ 89 tentang toleransi logam berat pada makanan.

- Kualitas suhu, pH, kecerahan, DO, BOD, yang diteliti umumnya masih dalam kisaran yang dipersyaratkan untuk kegiatan budidaya perikanan (PP No. 82 Tahun 2001), sedangkan amonia dan COD sudah melebihi ambang batas.

- Kandungan TOM mempunyai kisaran nilai 115-117,5 $\mathrm{mg} / \mathrm{L}$ melebihi ambang batas, sedangkan TSS 66-72 mg/L masih dalam kisaran yang ditetapkan.

\section{UCAPAN TERIMA KASIH}

Ucapan terima kasih penulis sampaikan pada BPPDN Ristekdikti yang telah membantu secara finansial dalam bentuk beasiswa studi Program Doktor di FPIK-UB

\section{DAFTAR PUSTAKA}

Andriyani, N. 2005. Kualitas perairan Waduk Sermo. Prosiding Seminar Nasional Biologi dan Akuakultur Berkelanjutan. Fakultas Biologi Program Pascasarjana Perikanan dan Kelautan, Universitas Jenderal Soedirman, Purwokerto. p. 149153.

Anonim, 2016. Bangun Kedaulatan Maritim, Indonesia Harus Lakukan Revolusi Mental. http://ekonomi.

kompas.com/read/2016/11/17/140 000226/bangun.kedaulatan.mariti m.indonesia.harus.lakukan.revolus i.mental. Diakses 30 Nopember 2017.

Connel, D.W. dan G. J. Miller. 1995. Kimia dan Ekotoksikologi Pencemaran. (terjemahan: Yanti Kastoer). UI-Press. Jakarta. P. 520.

Effendi, H. 2003. Telaah Kualitas Air Bagi Pengelolaan Sumber Daya dan Lingkungan Perairan. Kanisius: Yogyakarta.

Elmer, P. 2000. Analytical Methods for Atomic Absorbtion Spectrometry. PerkinElmer Instruments LLC, Singapore.

Fajri, N.E. 2001. Analisis Kandungan Logam Berat $\mathrm{Hg}, \mathrm{Cd}$, dan $\mathrm{Pb}$ 
dalam Air Laut, Sedimen, dan Tiram (Carassostrea cucullata) di Perairan Pesisir Kecamatan Pedes. Kabupaten Karawang. Jawa Barat. Tesis. Program Pascasarjana, IPB. Bogor.

Haritash, $\quad$ C.P. Kaushik,. 2009. Biodegradation aspects of Polycyclic Aromatic Hydrocarbons (PAHs): A review. Journal of Hazardous Materials. 169: $1-15$.

Everaat, J.M. 1989. Netherland Journal of Sea Research. 23(4): 403-413.

Manassrisuksi, K., M. Weir, and Y.A. Hussin. 2001. Assesment of mangrove rehabilitation programme using remote sensing and GIS: a case study of Amphur Khlung, Chantaburi Province, Eastern Thailand. 22nd Asian Conference on Remote Sensisng. Singapore 5-9 November 2001.

Ong, J.E. 2002. The hidden costs of mangrove services: use of mangroves for shrimp aquaculture. International Science Round Table for the Media, Bali Indonesia, 4 June 2002. Joint event of ICSU, IGBP, IHDP, WCRP. DIVERSITAS and START.

Rozak, A., dan E. Rochyatun. 2007. Pemantauan Kadar Logam Berat dalam Sedimen di Perairan Teluk Jakarta. Makara Sains. 11(1): 28 36.
Thayib S.S. dan H. Razak, 1981. Prosiding: Seminar dan Kongres Nasional Biologi VI. Surabaya. Indonesia. p.196-217. 